\title{
The Impact of Recent Advances in Endoscopic Ultrasound-Guided Tissue Acquisition on the Management of Pancreatic Cancer
}

\author{
Susana Marques ${ }^{a}$ Miguel Bispo ${ }^{a}$ Ricardo Rio-Tinto ${ }^{a}$ Paulo Fidalgo $^{a}$ \\ Jacques Devière ${ }^{a, b}$ \\ ${ }^{a}$ Department of Gastroenterology and Digestive Endoscopy, Champalimaud Foundation, Lisbon, Portugal; \\ ${ }^{b}$ Department of Gastroenterology, Hepatopancreatology, and Digestive Oncology, Erasme University Hospital - \\ Université Libre de Bruxelles, Brussels, Belgium
}

\section{Keywords}

Endoscopic ultrasound - Fine-needle aspiration .

Fine-needle biopsy · Pancreatic cancer · Personalised medicine

\section{Abstract}

Over the last few decades, endoscopic ultrasound (EUS)guided tissue acquisition has become the method of choice for the pathological diagnosis of solid pancreatic lesions. Due to its high diagnostic yield and low complication rate, EUS-guided tissue acquisition has surpassed percutaneous sampling techniques. For many years, EUS-guided fine-needle aspiration (EUS-FNA) was traditionally used to obtain cytological aspirates of solid pancreatic lesions, with sensitivity values ranging from 80 to $90 \%$ for the diagnosis of malignancy. Nevertheless, despite numerous technical advances, EUS-FNA still presents some limitations. Therefore, EUSguided fine-needle biopsy (EUS-FNB) has been introduced to provide tissue core biopsies, allowing histological assessment. A newly developed generation of FNB needles has demonstrated an outstanding diagnostic accuracy of over 95\% for solid pancreatic lesions and provides samples appropriate for ancillary testing, such as immunohistochemistry and tumour molecular profiling. As a result, EUS-FNB is rapidly replacing EUS-FNA and is now the recommended technique for EUS-guided tissue acquisition in pancreatic cancer. Furthermore, with the recent expansion of neoadjuvant treatment criteria and with the advent of novel and personalised anti-cancer therapies, EUS-FNB is gaining a pivotal role in pancreatic cancer management and might soon be generalised to all patients, independent of disease stage. In this article, the authors present an updated review of the role of EUS-guided tissue acquisition in pancreatic cancer. Current indications, several technical aspects and new applications of EUS-FNA and EUS-FNB are discussed.

\section{(C) 2020 Sociedade Portuguesa de Gastrenterologia Published by S. Karger AG, Basel}

\section{O impacto dos recentes avanços na aquisição de tecido guiada por ecoendoscopia na abordagem do cancro do pâncreas}

\section{Palavras Chave}

Ecoendoscopia · Aspiração por agulha fina · Biópsia por agulha fina · Cancro do pâncreas · Medicina personalizada karger@karger.com www.karger.com/pjg

Karger $\stackrel{\text { ' }}{5}$

BOPEN ACCESS
(C) 2020 Sociedade Portuguesa de Gastrenterologia Published by S. Karger AG, Basel

This article is licensed under the Creative Commons AttributionNonCommercial-NoDerivatives 4.0 International License (CC BY NC-ND) (http://www.karger.com/Services/OpenAccessLicense). Usage and distribution for commercial purposes as well as any distribution of modified material requires written permission.
Susana Marques

Department of Gastroenterology and Digestive Endoscopy

Champalimaud Foundation, Av. Brasília

PT-1400-038 Lisbon (Portugal)

susana.marques@fundacaochampalimaud.pt 


\section{Resumo}

Nas últimas décadas, a aquisição de tecido por ecoendoscopia tornou-se o método de eleição para o diagnóstico patológico de lesões sólidas do pâncreas. Devido à sua elevada capacidade diagnóstica e baixa taxa de complicações, a aquisição de tecido por ecoendoscopia ultrapassou as técnicas de biópsia por via percutânea. Durante muito anos, a aspiração com agulha fina guiada por ecoendoscopia (EUS-FNA) foi tradicionalmente usada para obter aspirados citológicos de lesões sólidas do pâncreas, com valores de sensibilidade que variam entre os $80 \%$ e os $90 \%$ no diagnóstico de malignidade. Contudo, apesar de numerosos avanços técnicos, a EUS-FNA apresenta ainda algumas limitações. Assim, a biópsia com agulha fina guiada por ecoendoscopia (EUS-FNB) foi introduzida para obter biópsias com cores de tecido, permitindo avaliação histológica. Uma nova geração de agulhas de FNB recentemente desenvolvida demonstra uma acuidade diagnóstica excecional acima de 95\% nas lesões sólidas do pâncreas e obtém amostras adequadas para estudos ancilares, designadamente imunohistoquímica e caracterização molecular tumoral. Por conseguinte, a EUS-FNB está rapidamente a substituir a EUS-FNA e é hoje a técnica recomendada para aquisição de tecido no cancro do pâncreas. Além disso, com a recente expansão dos critérios para tratamento neoadjuvante e com o advento de terapias anti-tumorais novas e personalizadas, a EUS-FNB está a adquirir um papel essencial na abordagem do cancro do pâncreas e poderá em breve ser generalizada a todos os doentes, independentemente do estádio da doença. Neste artigo, os autores apresentam uma revisão atualizada do papel da aquisição de tecido por ecoendoscopia no cancro do pâncreas. As indicações atuais, vários aspetos técnicos e novas aplicações da EUS-FNA e EUS-FNB são discutidos.

(c) 2020 Sociedade Portuguesa de Gastrenterologia Publicado por S. Karger AG, Basel

\section{Introduction}

Endoscopic ultrasound (EUS)-guided tissue acquisition has become the method of choice for the pathological diagnosis of solid pancreatic masses as it is a safe and accurate sampling technique. The most important role of EUS-guided sampling in pancreatic cancer management is the acquisition of pancreatic tissue for tumour diagnosis [1-3]. Additionally, EUS may add relevant information for pancreatic cancer staging, being particularly useful in the assessment of small and ill- defined pancreatic lesions, in the determination of tumour involvement of the portal venous confluence, in the characterisation of loco-regional lymph nodes, and in the diagnosis of small amounts of ascites undetected by other imaging techniques [4]. For EUS-guided sampling, either the traditional fine-needle aspiration (FNA) needles or the newer fine-needle biopsy (FNB) needles can be used.

For many years, EUS-guided FNA (EUS-FNA) has been an established and widely used sampling technique in the evaluation of solid pancreatic lesions. It provides samples of cells adequate for cytological analysis, allowing the recognition of features suggestive or diagnostic of malignancy with high sensitivity and specificity. Four meta-analyses have shown that EUS-FNA is very accurate for the diagnosis of solid pancreatic masses (sensitivity $85-92 \%$ and specificity 94-100\%) [5-8]. Compared with other percutaneous techniques, such as ultrasound and computed tomography-guided sampling, EUS-FNA has a higher sensitivity ( 84 vs. $62 \%)$ and a higher diagnostic accuracy $(80$ vs. $72 \%$ ) [9]. EUS-FNA is also a very safe procedure with a low complication rate $(2.4 \%)$. The most commonly reported complication is acute pancreatitis, and most cases are mild [10].

More recently, with the development of a new generation of FNB needles, it has been possible to perform tissue core biopsies that allow a broader histological assessment. This new generation of FNB needles has an outstanding diagnostic accuracy of over 95\% for solid pancreatic lesions [11-14] and allows ancillary testing, such as immunohistochemistry and tumour molecular profiling [1517]. Therefore, as we enter into the era of personalised medicine and precision therapy, EUS-guided FNB (EUSFNB) is rapidly replacing EUS-FNA as the procedure of choice for EUS-guided tissue acquisition in pancreatic cancer.

Given these recent advances, the authors present an updated review of the role of EUS-guided tissue acquisition in pancreatic cancer. Current indications, several technical aspects and new applications of EUS-FNA and EUS-FNB are discussed. With the use of PubMed, Medline, Scopus and Google, a systematic literature review was conducted until April 2020 based on the search terms: "pancreatic cancer", "EUS-guided fine-needle aspiration", "EUS-guided fine-needle biopsy", and "personalised medicine." Prospective/comparative studies and international consensus statements/management guidelines were preferred.
Marques/Bispo/Rio-Tinto/Fidalgo/ Devière 
Indications for EUS-Guided Tissue Acquisition in

Pancreatic Cancer

According to the most recent international guidelines on pancreatic cancer, pathological diagnosis of pancreatic adenocarcinoma is mandatory before chemotherapy. Therefore, EUS-guided sampling is recommended in patients with borderline resectable or locally advanced disease who are candidates for neoadjuvant treatment and in patients with metastatic disease for whom palliative treatment is indicated. These two sets of patients account for $80-85 \%$ of all pancreatic cancer patients $[1,2]$. Also, in patients with resectable disease (that accounts for the remainder $15-20 \%$ of the patients), EUS-guided tissue acquisition should be considered to establish the pathological diagnosis of pancreatic cancer before surgery, thus potentially reducing the number of unnecessary surgeries for benign diseases that mimic pancreatic cancer (e.g., autoimmune pancreatitis, focal chronic pancreatitis, and lymphoma). In fact, in several surgical series, the rate of surgical intervention for pancreatic lesions misdiagnosed as pancreatic cancer ranged between 5 and 10\% [18-20]. Additionally, with the recent expansion of neoadjuvant treatment indications to include patients with potentially resectable disease (namely those with high-risk features, such as CA19.9 $>500 \mathrm{UI} / \mathrm{mL}$, large primary tumour, suspicion of regional lymph node metastases, persistent pain, significant weight loss, and poor general condition [1]), EUS-guided tissue acquisition might soon be generalised to all patients with pancreatic cancer, independent of disease stage.

\section{EUS-Guided Fine-Needle Aspiration}

EUS-FNA has been an invaluable tool for the pathological diagnosis of solid pancreatic lesions, allowing the acquisition of cytological aspirates adequate for obtaining a diagnosis of malignancy with sensitivity values ranging from 80 to $90 \%$ [5-8]. Several types of FNA needles with calibres ranging from 19 to 25 gauge are available. To date, numerous studies have compared different calibres of FNA needles and also distinct technical aspects of the EUS-FNA procedure.

\section{FNA Needle Calibre}

Due to its smaller calibre, the 25-gauge FNA needle potentially offers a technical advantage when sampling very fibrotic (hard) solid lesions compared to larger-calibre needles. In addition, its greater flexibility allows a better manoeuvrability, particularly when sampling pan-

EUS-Guided Tissue Acquisition in

Pancreatic Cancer creatic head and uncinate masses from the duodenum. Three meta-analyses have shown that the 25-gauge FNA needle increases the diagnostic sensitivity (with similar specificity), when compared with the 22 -gauge FNA needle [21-23]. Nevertheless, due to the fact that these results did not reach statistical significance in two of these metaanalyses [21,22], both calibres ( 25 and 22 gauge) are recommended when sampling solid pancreatic lesions [3]. Compared to thinner needles, the 19-gauge FNA needle tends to be stiffer and harder to manoeuvre and is associated with increased technical failure [24].

\section{Negative Pressure}

Several methods of creating negative pressure to aspirate the sample into the needle have been described. The traditional aspiration/suction technique relies on creating a negative pressure applied via the syringe that is attached to the needle. When sampling malignant solid pancreatic lesions, the use of $10-\mathrm{mL}$ negative pressure results in a higher sensitivity and a higher diagnostic yield compared to no suction $[25,26]$ and is, therefore, recommended [3]. The "wet suction" technique relies on pre-flushing the needle with saline to replace the column of air with fluid, followed by applying negative pressure. Theoretically, when using this technique, the negative pressure applied via the syringe is better transmitted to the needle tip. Results from a randomised controlled trial showed that the "wet suction" technique increases sample cellularity and quality when compared to the traditional aspiration/suction method [27]. The "stylet slow-pull" technique involves the slow and gradual removal of the needle stylet while moving the needle within the lesion to create a minimal negative pressure (without using the syringe). This method has a similar diagnostic yield for solid pancreatic lesions compared to the traditional aspiration technique $[28,29]$.

\section{Puncture Technique}

Several FNA puncture techniques have been described over the past few years. The traditional method relies on positioning the needle tip at one location within the mass and then moving it back and forth 16 times to procure tissue $(1 \times 16)$. The "fanning technique" was developed to allow the acquisition of tissue from different lesion areas and involves positioning the needle tip in four different areas within the mass and then moving it back and forth four times in each area $(4 \times 4)$. Compared with the traditional method, the "fanning technique" is associated with increased diagnostic yield on the first needle pass and a lower number of passes to obtain a pathological diagnosis [30]. 
Table 1. Types of EUS-FNA and EUS-FNB needles available

\begin{tabular}{|c|c|c|c|c|c|c|}
\hline $\begin{array}{l}\text { EUS-FNA/ } \\
\text { FNB }\end{array}$ & EUS-FNA & \multicolumn{5}{|l|}{ EUS-FNB } \\
\hline Photo & & & & & & \\
\hline
\end{tabular}

\section{Rapid On-Site Pathologist Evaluation}

Though it has not been demonstrated whether the presence of an on-site pathologist improves the diagnostic yield of EUS-FNA for solid pancreatic lesions, Rapid On-Site Pathologist Evaluation (ROSE) has the potential to reduce the number of needle passes to obtain a pathological diagnosis [31,32]. Nevertheless, the application of ROSE is limited by the availability of trained cytopathologists in each centre and by its additional cost. According to the guidelines, when performing EUS-FNA of solid pancreatic lesions in the absence of ROSE, 3-4 needle passes should be performed, as this is the number of passes required to reach a sensitivity of at least $90 \%$ for the diagnosis of malignancy $[3,30,33,34]$.

Despite numerous technical advances, EUS-FNA is still associated with some limitations. For example, cellularity is often low and tissue architecture is not preserved, limiting the use of diagnostic immunohistochemistry studies, which are key in the differential diagnosis of pancreatic cancer (as they are needed to establish the diagnosis of conditions such as autoimmune pancreatitis, neuroendocrine tumours, and lymphoma). In addition, in very necrotic or fibrotic tumours, such as pancreatic adenocarcinoma, the procurement of viable tumour cells is even more difficult and frequently insufficient for diagnosis.

\section{EUS-Guided Fine-Needle Biopsy}

The demand to acquire samples with increased cellularity and with tissue architecture preservation has led to the development of a new type of needle, the FNB needle.
These needles have sharp cutting edges to cleanly cut the tissue within a lesion. They were specifically designed to obtain core tissue samples, allowing a more complete histological assessment.

To date, there have been three generations of FNB needles (Table 1). The first generation of FNB needles was the Quick-Core Needle (Cook Endoscopy, Limerick, Ireland), a Tru-Cut 19-gauge needle that rapidly fell into disuse due to poor flexibility and technical issues. The second generation of FNB needles was the ProCore Needle (Cook Endoscopy, Limerick, Ireland), a needle with a reverse bevel design that is available in 19-, 22-, and 25-gauge calibres. Two meta-analyses have shown that, despite having a diagnostic yield similar to FNA needles, reverse bevel needles reduce the number of needle passes needed to establish a pathological diagnosis $[35,36]$. Therefore, when performing EUS-FNB of solid pancreatic lesions in the absence of ROSE, 2-3 needle passes are sufficient to ensure a sensitivity of at least $90 \%$ for the diagnosis of malignancy [3, 35, 37-39].

Recently, the third generation of FNB needles has been introduced, and it includes three different types of needles:

- The new ProCore Needle (Cook Endoscopy, Limerick, Ireland), a forward-facing bevel 20-gauge needle;

- The SharkCore Needle (Medtronic Corporation, Newton, MA, USA), a fork-tip needle (with 6 cutting edges) available in 19-, 22- and 25-gauge calibres;

- The Acquire Needle (Boston Scientific Corporation, Natick, MA, USA), a crown-tip needle (Franseen needle) available in 22- and 25-gauge calibres.

Facciorusso et al. [11] reported the results of a very recent meta-analysis that evaluated the diagnostic perfor- 
mance of this new generation of FNB needles, in particular of the crown- and fork-tip needles. This meta-analysis showed that these two FNB needles have an outstanding diagnostic accuracy for solid pancreatic lesions, reaching a value of $96 \%$, with no difference between the crown and fork-tip needles ( 97 vs. $95 \%$ respectively, $p=0.8$ ). One study included in this meta-analysis was a prospective randomised trial conducted by Bang et al. [12]. According to this study, with only two dedicated needle passes and using the "fanning technique," the diagnostic cell block adequacy was 96 and 92\% for crown- and fork-tip needles, respectively. Due to the fact that this new generation of FNB needles is very recent, studies specifically testing different needle calibres and different procedure techniques (e.g., aspiration/suction, "stylet slow pull") are still scarce, and no recommendations exist regarding this point. There are also few studies focused on the safety of EUS-FNB needles compared to EUS-FNA needles, although the safety profile appears to be similarly very good [11].

To date, few data are available on the comparison between third-generation FNB needles and standard FNA needles. van Riet el al. [40] reported the results of a multicentre randomised controlled study comparing the diagnostic performance of these new-generation FNB needles (20-gauge forward-facing bevel needle) with FNA needles (22-gauge needle). According to this study, EUSFNB outperformed EUS-FNA in terms of histological yield (77 vs. $44 \%, p<0.001$ ) and accuracy for malignancy ( 87 vs. $78 \%, p=0.002$ ) for pancreatic and non-pancreatic solid lesions. A large retrospective study conducted by Bang et al. [41] included more than 2,000 patients with biliopancreatic lesions undergoing EUS-FNA (22- and 25 -gauge needles) or EUS-FNB (22-gauge crown- and fork-tip needles). According to the results of this study, EUS-FNB not only achieved a higher diagnostic yield on cell blocks ( 92 vs. $71 \%, p<0.001$ ), but also reduced the number of needle passes needed to achieve sample adequacy for ROSE (1 [IQR 1-2] vs. 2 [IQR 1-3], $p<0.001$ ) compared with EUS-FNA. In another study from Bang et al. [15], when compared to standard FNA needles (22-gauge needles), third-generation FNB needles (22-gauge crown-tip needles) provided tissue samples with a 20 -fold higher area of tissue $\left(6.1\right.$ vs. $0.28 \mathrm{~mm}^{2}, p<$ $0.001)$ that were much more conducive to immunohistochemistry testing ( 100 vs. $68 \%, p<0.001$ ).

Given the increase in diagnostic yield per needle pass, the use of third-generation FNB needles may potentially obviate the need for ROSE, thus reducing procedure time and cost. To assess if ROSE is still needed when perform-

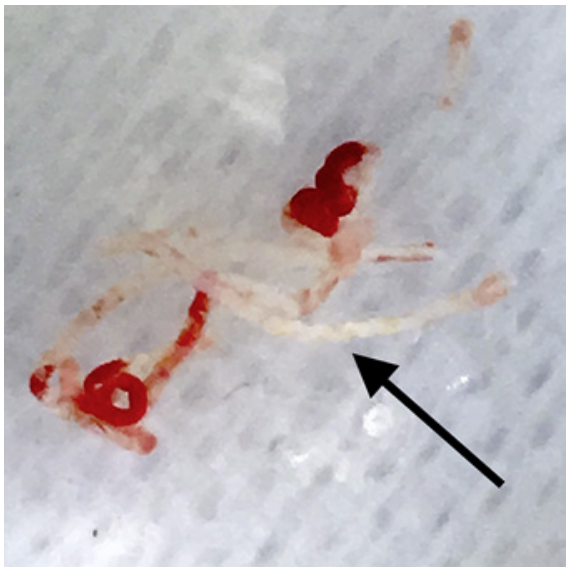

Fig. 1. Macroscopic visible histological core (white-yellowish fragments: arrow) of a pancreatic adenocarcinoma obtained by EUSFNB (22-gauge crown-tip needle).

ing EUS-FNB of solid pancreatic lesions with these needles, there is an ongoing multicentre randomised noninferiority trial comparing the diagnostic accuracy of EUS-FNB with or without ROSE [42]. Also, 2 recent studies have already evaluated the diagnostic performance of macroscopic on-site evaluation (MOSE) using a newgeneration FNB needle (22-gauge crown-tip needle) for sampling solid pancreatic lesions. These studies demonstrated that MOSE might limit needle passes, as a histological core (Fig. 1) could be easily identified by the endosonographer in more than $90 \%$ of cases after a single pass, and that a very high diagnostic accuracy (97\%) could be achieved without ROSE $[13,14]$.

In light of these outstanding results, several experts have begun to advocate the use of third-generation FNB needles as the new standard procedure for sampling solid pancreatic lesions instead of conventional FNA needles. Similarly, the 2020 National Comprehensive Cancer Network guidelines on pancreatic adenocarcinoma now recommend EUS-FNB as the sampling procedure of choice for pathological diagnosis [1].

\section{New Applications of EUS-FNB in the Era of \\ Personalised Medicine}

Despite improvements in diagnostic modalities and management strategies, including surgery and medical therapy, the outcome of pancreatic cancer remains poor. With recent advances in understanding the molecular landscape of pancreatic cancer coupled with the availabil- 
ity of new targeted anti-cancer therapies, there is renewed enthusiasm for individualised precision treatment in order to improve patient prognosis. Over the last decade, several genomic studies have revealed distinct subtypes of pancreatic adenocarcinoma based on the molecular features of tumour cells and stromal microenvironment. These subtypes are associated with different tumour behaviours and patient outcomes and may help identifying potential new therapeutics targets $[43,44]$. The $2020 \mathrm{Na}$ tional Comprehensive Cancer Network guidelines recommend tumour gene profiling for patients with locally advanced or metastatic disease who are candidates for anti-cancer therapy to identify potentially targetable mutations [1]. However, most identified mutations have failed to impact clinical practice and, currently, only benefit a small proportion of pancreatic cancer patients [45]. An alternative and complementary path to patient tailored-medicine involves the development of patient-derived organoids and xenograft models that allow anticancer drug susceptibility testing and, therefore, might aid clinicians in making treatment decisions. Until recently, only resected pancreas cancer specimens had been used to obtain sufficient tissue for performing ancillary studies, such as genomic profiling and establishment of organoid and xenograft models [46]. However, as only a minority of pancreatic cancer patients undergo surgery, this approach is not useful for most patients. The recent development of third-generation FNB needles improved the ability to obtain tumour core biopsies with preserved tissue architecture that contains both tumour cells and desmoplastic stroma, allowing the performance of ancillary studies at the time of diagnosis and, therefore, potentially determining precise treatment strategies early in the disease course.

There is growing evidence that EUS-FNB for pancreatic adenocarcinoma provides tumour samples that are an excellent source for genomic analysis, and some studies have already demonstrated its superiority over EUSFNA. Elhanafi et al. [16] reported that EUS-FNB is more likely to result in sufficient tissue sampling for tumour molecular profiling using target next-generation sequencing compared with EUS-FNA (91 vs. 67\%). Also, a prospective randomised controlled trial conducted by Kandel et al. [17] showed that sufficient DNA for whole exome sequencing on the first pass was obtained more frequently with EUS-FNB needles compared to EUSFNA needles (74 vs. 54\%). Additionally, development of tumour models, such as organoid and xenograft, has also been possible using EUS-FNB samples from pancreatic cancer patients. La Comb et al. [47] reported that success- ful organoid creation was feasible in $84 \%$ of EUS-FNB specimens. Hermans et al. [48] developed a patient-derived xenograft model by transferring tumour tissue obtained by EUS-FNB, which achieved an engraftment rate of $60 \%$. Taken together, these promising findings have set the stage for EUS-FNB in the era of personalised medicine in pancreas cancer.

\section{Conclusion}

EUS-guided tissue acquisition is the gold standard for sampling solid pancreatic lesions as it offers a high diagnostic yield with low risk of complications [1-3]. Traditionally, EUS-FNA was the sampling procedure of choice, allowing the acquisition of cytological aspirates adequate for obtaining a diagnosis of malignancy with sensitivity values ranging from 80 to $90 \%$ [5-8]. More recently, with the development of a new generation of FNB needles, it has been possible to perform tissue core biopsies that allow a broader histological assessment. Hence, not only has the diagnostic accuracy for solid pancreatic lesions increased, reaching a value of over 95\% [11-14] and potentially obviating the need for ROSE, but also the samples obtained are appropriate for ancillary studies, such as immunohistochemistry and tumour molecular profiling [15-17]. Together with the recent expansion of neoadjuvant treatment indications and the advent of novel and personalised anti-cancer therapies, EUS-FNB is gaining a pivotal role in pancreatic cancer management and might soon be generalised to all patients, independent of disease stage.

\section{Conflict of Interest Statement}

All authors have no personal conflicts of interest or financial relationships relevant to this publication to disclose.

Funding Sources

None to report.

\section{Author Contributions}

Susana Marques: article concept and design, literature review, and draft of the manuscript. Miguel Bispo, Ricardo Rio-Tinto, Paulo Fidalgo, and Jacques Devière: literature review and critical review of the manuscript. 
1 Tempero MA, Malafa MP, Al-Hawary M, Asbun H, Behrman SW, Benson AB 3rd, et al. Pancreatic Adenocarcinoma, Version 1.2020. Plymouth Meeting: NCCN; 2019.

2 Ducreux M, Cuhna AS, Caramella C, Hollebecque A, Burtin P, Goéré D, et al.; ESMO Guidelines Committee. Cancer of the pancreas: ESMO Clinical Practice Guidelines for diagnosis, treatment and follow-up [published correction appears in Ann Oncol. 2017 Jul 1; 28(suppl_4):iv167-iv168]. Ann Oncol. 2015 Sep;26 Suppl 5:v56-68.

3 Polkowski M, Jenssen C, Kaye P, Carrara S, Deprez P, Gines A, et al. Technical aspects of endoscopic ultrasound (EUS)-guided sampling in gastroenterology: European Society of Gastrointestinal Endoscopy (ESGE) Technical Guideline - March 2017. Endoscopy. 2017 Oct;49(10):989-1006.

4 Suzuki R, Irisawa A, Bhutani MS, Hikichi T, Takagi T, Shibukawa G, et al. An automated spring-loaded needle for endoscopic ultrasound-guided abdominal paracentesis in cancer patients. World J Gastrointest Endosc. 2014 Feb;6(2):55-9.

5 Hébert-Magee S, Bae S, Varadarajulu S, Ramesh J, Frost AR, Eloubeidi MA, et al. The presence of a cytopathologist increases the diagnostic accuracy of endoscopic ultrasoundguided fine needle aspiration cytology for pancreatic adenocarcinoma: a meta-analysis. Cytopathology. 2013 Jun;24(3):159-71.

6 Hewitt MJ, McPhail MJ, Possamai L, Dhar A, Vlavianos P, Monahan KJ. EUS-guided FNA for diagnosis of solid pancreatic neoplasms: a meta-analysis. Gastrointest Endosc. 2012 Feb; 75(2):319-31.

7 Puli SR, Bechtold ML, Buxbaum JL, Eloubeidi MA. How good is endoscopic ultrasoundguided fine-needle aspiration in diagnosing the correct etiology for a solid pancreatic mass?: A meta-analysis and systematic review. Pancreas. 2013 Jan;42(1):20-6.

8 Chen J, Yang R, Lu Y, Xia Y, Zhou H. Diagnostic accuracy of endoscopic ultrasoundguided fine-needle aspiration for solid pancreatic lesion: a systematic review. J Cancer Res Clin Oncol. 2012 Sep;138(9):1433-41.

9 Horwhat JD, Paulson EK, McGrath K, Branch MS, Baillie J, Tyler D, et al. A randomized comparison of EUS-guided FNA versus CT or US-guided FNA for the evaluation of pancreatic mass lesions. Gastrointest Endosc. 2006 Jun;63(7):966-75.

10 Wang KX, Ben QW, Jin ZD, Du YQ, Zou DW, Liao $Z$, et al. Assessment of morbidity and mortality associated with EUS-guided FNA: a systematic review. Gastrointest Endosc. 2011 Feb;73(2):283-90.

11 Facciorusso A, Del Prete V, Buccino VR, Purohit P, Setia P, Muscatiello N. Diagnostic yield of Franseen and Fork-Tip biopsy needles for endoscopic ultrasound-guided tissue acquisition: a meta-analysis. Endosc Int Open. 2019 Oct;7(10):E1221-30.
12 Bang JY, Hebert-Magee S, Navaneethan U, Hasan MK, Hawes R, Varadarajulu S. Randomized trial comparing the Franseen and Fork-tip needles for EUS-guided fine-needle biopsy sampling of solid pancreatic mass lesions. Gastrointest Endosc. 2018 Jun;87(6): 1432-8.

13 Leung Ki EL, Lemaistre AI, Fumex F, Gincul $\mathrm{R}$, Lefort C, Lepilliez V, et al. Macroscopic onsite evaluation using endoscopic ultrasound fine needle biopsy as an alternative to rapid onsite evaluation. Endosc Int Open. 2019 Feb; 7(2):E189-94.

14 Mukai S, Itoi T, Yamaguchi $\mathrm{H}$, Sofuni A, Tsuchiya $\mathrm{T}$, Tanaka $\mathrm{R}$, et al. A retrospective histological comparison of EUS-guided fineneedle biopsy using a novel franseen needle and a conventional end-cut type needle. Endosc Ultrasound. 2019 Jan-Feb;8(1):50-7.

15 Bang JY, Hebert-Magee S, Navaneethan U, Hasan MK, Hawes R, Varadarajulu S. EUSguided fine needle biopsy of pancreatic masses can yield true histology. Gut. 2018 Dec; 67(12):2081-4.

16 Elhanafi S, Mahmud N, Vergara N, Kochman ML, Das KK, Ginsberg GG, et al. Comparison of endoscopic ultrasound tissue acquisition methods for genomic analysis of pancreatic cancer. J Gastroenterol Hepatol. 2019 May; 34(5):907-13.

17 Kandel P, Nassar A, Graddy C, Gomez V, Raimondo M, Woodward T, et al. Mo1345 whole exome sequencing and genomic profiling of pancreas tumor tissue obtained with a novel fork-tipped EUS-guided fine needle core biopsy: a randomized controlled trial. Gastrointest Endosc. 2018;87(6):455-6.

18 Smith CD, Behrns KE, van Heerden JA, Sarr MG. Radical pancreatoduodenectomy for misdiagnosed pancreatic mass. Br J Surg. $1994 \mathrm{Apr} ; 81(4): 585-9$.

19 Thompson JS, Murayama KM, Edney JA, Rikkers LF. Pancreaticoduodenectomy for suspected but unproven malignancy. Am J Surg. 1994 Dec;168(6):571-3.

20 Abraham SC, Wilentz RE, Yeo CJ, Sohn TA, Cameron JL, Boitnott JK, et al. Pancreaticoduodenectomy (Whipple resections) in patients without malignancy: are they all 'chronic pancreatitis'? Am J Surg Pathol. 2003 Jan; 27(1):110-20.

21 Facciorusso A, Stasi E, Di Maso M, Serviddio G, Ali Hussein MS, Muscatiello N. Endoscopic ultrasound-guided fine needle aspiration of pancreatic lesions with 22 versus 25 Gauge needles: A meta-analysis. United European Gastroenterol J. 2017 Oct;5(6):846-53.

22 Xu MM, Jia HY, Yan LL, Li SS, Zheng Y. Comparison of two different size needles in endoscopic ultrasound-guided fine-needle aspiration for diagnosing solid pancreatic lesions: A meta-analysis of prospective controlled trials. Medicine (Baltimore). 2017 Feb;96(5):e5802.
23 Madhoun MF, Wani SB, Rastogi A, Early D, Gaddam S, Tierney WM, et al. The diagnostic accuracy of 22-gauge and 25-gauge needles in endoscopic ultrasound-guided fine needle aspiration of solid pancreatic lesions: a metaanalysis. Endoscopy. 2013;45(2):86-92.

24 Song TJ, Kim JH, Lee SS, Eum JB, Moon SH, Park DY, et al. The prospective randomized, controlled trial of endoscopic ultrasoundguided fine-needle aspiration using $22 \mathrm{G}$ and 19G aspiration needles for solid pancreatic or peripancreatic masses. Am J Gastroenterol. 2010 Aug; 105(8):1739-45.

25 Tarantino I, Di Mitri R, Fabbri C, Pagano N, Barresi L, Granata A, et al. Is diagnostic accuracy of fine needle aspiration on solid pancreatic lesions aspiration-related? A multicentre randomised trial. Dig Liver Dis. 2014 Jun; 46(6):523-6.

26 Lee JK, Choi JH, Lee KH, Kim KM, Shin JU, Lee $\mathrm{JK}$, et al. A prospective, comparative trial to optimize sampling techniques in EUSguided FNA of solid pancreatic masses. Gastrointest Endosc. 2013 May;77(5):745-51.

27 Attam R, Arain MA, Bloechl SJ, Trikudanathan G, Munigala S, Bakman Y, et al. "Wet suction technique (WEST)": a novel way to enhance the quality of EUS-FNA aspirate. Results of a prospective, single-blind, randomized, controlled trial using a 22-gauge needle for EUS-FNA of solid lesions. Gastrointest Endosc. 2015;81(6):1401-7.

28 Kin T, Katanuma A, Yane K, Takahashi K, Osanai M, Takaki R, et al. Diagnostic ability of EUS-FNA for pancreatic solid lesions with conventional 22-gauge needle using the slow pull technique: a prospective study. Scand J Gastroenterol. 2015 Jul;50(7):900-7.

29 Saxena P, El Zein M, Stevens T, Abdelgelil A, Besharati S, Messallam A, et al. Stylet slowpull versus standard suction for endoscopic ultrasound-guided fine-needle aspiration of solid pancreatic lesions: a multicenter randomized trial. Endoscopy. 2018 May;50(5): 497-504.

30 Bang JY, Magee SH, Ramesh J, Trevino JM, Varadarajulu S. Randomized trial comparing fanning with standard technique for endoscopic ultrasound-guided fine-needle aspiration of solid pancreatic mass lesions. Endoscopy. 2013 Jun;45(6):445-50.

31 Wani S, Mullady D, Early DS, Rastogi A, Collins B, Wang JF, et al. The clinical impact of immediate on-site cytopathology evaluation during endoscopic ultrasound-guided fine needle aspiration of pancreatic masses: a prospective multicenter randomized controlled trial. Am J Gastroenterol. 2015 Oct;110(10): 1429-39.

32 Lee LS, Nieto J, Watson RR, Hwang AL, Muthusamy VR, Walter L, et al. Randomized Noninferiority Trial Comparing Diagnostic Yield of Cytopathologist-guided versus 7 passes for EUS-FNA of Pancreatic Masses. Dig Endosc. 2016 May;28(4):469-75.
EUS-Guided Tissue Acquisition in Pancreatic Cancer
GE Port J Gastroenterol 2021;28:185-192 DOI: $10.1159 / 000510730$ 
33 Mohamadnejad M, Mullady D, Early DS, Collins B, Marshall C, Sams S, et al. Increasing Number of Passes Beyond 4 Does Not Increase Sensitivity of Detection of Pancreatic Malignancy by Endoscopic UltrasoundGuided Fine-Needle Aspiration. Clin Gastroenterol Hepatol. 2017 Jul;15(7):1071-1078. e2.

34 Bang JY, Hebert-Magee S, Trevino J, Ramesh J, Varadarajulu S. Randomized trial comparing the 22-gauge aspiration and 22-gauge biopsy needles for EUS-guided sampling of solid pancreatic mass lesions. Gastrointest Endosc. 2012 Aug;76(2):321-7.

35 Bang JY, Hawes R, Varadarajulu S. A metaanalysis comparing ProCore and standard fine-needle aspiration needles for endoscopic ultrasound-guided tissue acquisition. Endoscopy. 2016 Apr;48(4):339-49.

36 Oh HC, Kang H, Lee JY, Choi GJ, Choi JS. Diagnostic accuracy of 22/25-gauge core needle in endoscopic ultrasound-guided sampling: systematic review and meta-analysis. Korean J Intern Med (Korean Assoc Intern Med). 2016 Nov;31(6):1073-83.

37 Alatawi A, Beuvon F, Grabar S, Leblanc S, Chaussade S, Terris B, et al. Comparison of $22 \mathrm{G}$ reverse-beveled versus standard needle for endoscopic ultrasound-guided sampling of solid pancreatic lesions. United European Gastroenterol J. 2015 Aug;3(4):343-52.
38 Lee YN, Moon JH, Kim HK, Choi HJ, Choi $\mathrm{MH}$, Kim DC, et al. Core biopsy needle versus standard aspiration needle for endoscopic ultrasound-guided sampling of solid pancreatic masses: a randomized parallel-group study. Endoscopy. 2014 Dec;46(12):1056-62.

39 Iwashita T, Nakai Y, Samarasena JB, Park DH, Zhang Z, Gu M, et al. High single-pass diagnostic yield of a new 25-gauge core biopsy needle for EUS-guided FNA biopsy in solid pancreatic lesions. Gastrointest Endosc. 2013 Jun;77(6):909-15.

40 van Riet PA, Larghi A, Attili F, Rindi G, Nguyen NQ, Ruszkiewicz A, et al. A multicenter randomized trial comparing a 25 -gauge EUS fine-needle aspiration device with a 20 -gauge EUS fine-needle biopsy device. Gastrointest Endosc. 2019 Feb;89(2):329-39.

41 Bang JY, Kirtane S, Krall K, Navaneethan U, Hasan M, Hawes R, et al. In memoriam: Fineneedle aspiration, birth: Fine-needle biopsy: The changing trend in endoscopic ultrasound-guided tissue acquisition. Dig Endosc. 2019 Mar;31(2):197-202.

42 Crinò SF, Manfrin E, Scarpa A, Baldaque-Silva F, Carrara S, De Nucci G, et al. EUS-FNB with or without on-site evaluation for the diagnosis of solid pancreatic lesions (FROSENOR): protocol for a multicenter randomized non-inferiority trial. Dig Liver Dis. 2019 Jun; 51(6):901-6.
43 Lomberk G, Blum Y, Nicolle R, Nair A, Gaonkar KS, Marisa L, et al. Distinct epigenetic landscapes underlie the pathobiology of pancreatic cancer subtypes. Nat Commun. 2018 May;9(1):1978.

44 Puleo F, Nicolle R, Blum Y, Cros J, Marisa L, Demetter P, et al. Stratification of Pancreatic Ductal Adenocarcinomas Based on Tumor and Microenvironment Features. Gastroenterology. 2018 Dec;155(6):1999-2013.e3.

45 Singhi AD, George B, Greenbowe JR, Chung J, Suh J, Maitra A, et al. Real-Time Targeted Genome Profile Analysis of Pancreatic Ductal Adenocarcinomas Identifies Genetic Alterations That Might Be Targeted With Existing Drugs or Used as Biomarkers. Gastroenterology. 2019 Jun;156(8):2242-2253.e4.

46 Kandel P, Wallace MB. Recent advancement in EUS-guided fine needle sampling. J Gastroenterol. 2019 May;54(5):377-87.

47 Lacomb JF, Plenker D, Tiriac H, Bucobo JC, D'souza LS, Khokhar AS, et al. Single-Pass vs 2-Pass Endoscopic Ultrasound-Guided FineNeedle Biopsy Sample Collection for Creation of Pancreatic Adenocarcinoma Organoids. Clin Gastroenterol Hepatol. 2020 Feb;S1542-3565(20)30264-0.

48 Hermans E, Van der Merwe SW, Depreeuw J, Dekervel J, Radaelli E, Roskams T, et al. Successful application of endoscopic ultrasoundguided fine needle biopsy to establish pancreatic patient-derived tumor xenografts: a pilot study. Endoscopy. 2016 Nov;48(11):1016-22. 